\title{
A new species of Neopiciella Sama, 1988 (Coleoptera Ceram- bycidae) from western Sicily
}

\author{
Michele Bellavista', Pierpaolo Rapuzzi² \& Ignazio Sparacio ${ }^{3}$ \\ ${ }^{1}$ Via Carlo De Grossis 7, 90135 Palermo; michele.bellavista@gmail.com \\ ${ }^{2}$ Via Cialla 48, 33040 Prepotto, Udine, Italy; e-mail: info@,ronchidicialla.it \\ ${ }^{3}$ Via Principe di Paternò 3, 90144 Palermo; e-mail: edizionidanaus@gmail.com
}

\begin{abstract}
A new species of the genus Neopiciella Sama, 1988 (Coleoptera Cerambycidae) from Sicily is described. Neopiciella stefaniae $\mathrm{n}$. sp. is compared with the other species of this genus: $N$. sicula (Ganglbauer, 1885) from Sicily and N. kabyliana (Pic, 1896) from Algeria and Tunisia. Further information on the taxonomy, biology and geographical distribution of this small group of Beetles, and on N. stefaniae n. sp. in particular, are provided.
\end{abstract}

KEY WORDS Coleoptera, Cerambycidae; Neopiciella; new species; Sicily; North Africa.

Received 20.08.2020; accepted 09.12.2020; published online 30.12.2020

\section{INTRODUCTION}

The genus Neopiciella Sama, 1988 (Coleoptera Cerambycidae) has been introduced by Sama (1988) as a new name for Piciella Villiers, 1946 “(nomen nudum) nec Borchmann, 1936" with the following morphological characters: "pronoto più lungo che largo, munito di una sporgenza arrotondata ai lati poco avanti la metà, senza evidente solco trasversale prebasale. Antenne robuste con articoli terminali ingrossati, $4^{\circ}$ articolo più corto del $3^{\circ}, 6^{\circ}$ non più corto del $3^{\circ}$. Elitre ristrette verso l'apice, qui arrotondate. $2^{\circ}$ articolo dei tarsi posteriori non più lungo del $3^{\circ}$ " [pronotum longer than wide, with a rounded projection on the sides just ahead of the middle, without evident transverse prebasal groove. Antennae robust with thickened end segments, 4th segment shorter than 3rd, 6th segment no shorter than 3rd. Elytra narrowed towards the apex, rounded here. 2nd segment of the posterior tarsus no longer than the $3 \mathrm{rd}]$. The type species of the genus is Leptura sicula Ganglbauer, 1885 designed by Sama for Neopiciella. Villiers (1946) described Piciella without original designation.
Currently, this genus includes two species: $N$. sicula (Ganglbauer, 1885) from Sicily with type locality "Sicilie" (Ganglabauer, 1885) and $N$. kabyliana (Pic, 1896) (= suberis Chobaut, 1900) from Algeria and Tunisia with type locality "Algérie: forêt de Yakouren" (Pic, 1896).

Particularly, N. sicula is an uncommon species, cited for a few Sicilian locations, although it is widespread on the island along the northern mountain ridge from the Peloritani to the Sicani Mountains and around Palermo (Ragusa, 1924; Vitale, 1936; Sama \& Schurmann, 1980; Sparacio, 1999; Baviera \& Sparacio, 2002; Sabella \& Sparacio, 2004; Sama, 2005; Rapuzzi \& Sama, 2006; Bellavista et al., 2008; La Mantia et al., 2010; Rapuzzi, 2010; Baviera et al., 2017).

Neopiciella sicula is also reported as Critically Endangered (CR) in the Red List of Italian Saproxylic Beetles (Rapuzzi et al., 2014; Carpaneto et al., 2015).

In recent years, other new localities have been surveyed for $N$. sicula up to Monte Inici (Trapani) (Baviera et al., 2017). Further researches carried out on Sicilian xylophagous beetles highlighted the 
presence of this Cerambycidae also in other wood formations of the Trapani area. The study of these western populations has allowed us to highlight substantial morphological differences with the other known populations of Neopiciella and to describe a new species below.

ACRONYMS. CGS = Gianfranco Sama, Cesena, Italy, private collection. CIS = Ignazio Sparacio, Palermo, Italy, private collection. CMC = Michele Carraretto, Morgano, Treviso, Italy, private collection. $\mathrm{CMB}=$ Michele Bellavista, Palermo, Italy, private collection. $\mathrm{CPR}=$ Pierpaolo Rapuzzi, Cialla di Prepotto, Udine, Italy, private collection. $\mathrm{CSN}=$ Stefano Nappini, Castiglione della Pescaia, Grosseto, Italy, private collection. NHMW = Naturhistorisches Museum Wien, Wien, Austria.

\section{RESULTS}

\section{Systematics}

Ordo COLEOPTERA Linnaeus, 1758

Familia CERAMBYCIDAE Latreille, 1802

Subfamilia LEPTURINAE Latreille, 1802

Tribus LEPTURINI Latreille, 1802

Genus Neopiciella Sama, 1988

Neopiciella stefaniae n. sp. (Figs. 1, 2, 5, 6) htpp://zoobank.org:act:BE3F2957-46DF-45E99C0C-AB66A3B81242

TYPe MATERIAL. Holotypus male: Italy, Sicily, Trapani, Castellammare del Golfo, Monte Inici, 12.VI.2009 (CMB). Paratypes: same data of the holotype, 25.VI.2000, 1 ex (CMB); idem, 12.VI.2009, 5 ex (CMB); idem, 21.VII.2010, 1 ex (CMB); idem, 21.VI.2020, 5 males and 2 females (CIS); Bosco Scorace, 21.VI.2020, 1 male (CIS); Monte Sparagio, 21.VI.2020, 1 male and 2 females (CIS); Monte Sparagio, 28.VI.2020, I. Sparacio legit, 1 male (CPR); Monte Inici (TP), 10.VI.2009, I. Sparacio legit, 2 males and 1 female (CPR); idem, 1 male and 1 female, 21.VI.2020 (CPR).

OTHER EXAMINED MATERIAL. Neopicella sicula. Holotype (Fig. 1): the type series is made by a single specimen (female) in discreet conditions (it is missing the right hind tibia and the left tarsi of the hind leg, the right elytron shows a big hole due to an old pin), preserved in the Ganglbauer collection (NHMW). The specimen has the following labels: Sicilia [white label, handwritten by Ganglbauer] / Leptura si=/cula Gglb. Typ. [white label, handwritten by Ganglbauer] / TYPE [red label, printed] / sicula/Sicil. Ganglb. [white label handwritten by Ganglbauer].

Italy, Sicily, Palermo province, Piana degli Albanesi, 24.VI.1995, 1 male (CIS); Madonie Mountains: Pomieri, 17.VI.2008, 1 female (CIS); idem, 28.VI.2008 2 males and 1 female (CIS); idem, 6.VI.2009, 1 female (CIS); Bosco Ficuzza, Alpe Cucco, 20.VI.2009, 1 male (CIS); Bosco Ficuzza, Bivio Lupo, 20.VII.2009, 1 male (CIS); Palermo, 3.V.2001, 1 female (CIS); Palermo, 8.V.2020, 1 female (CIS); Bosco della Ficuzza, Fanuso, 25.VI. 2009, 1 male (CMB); idem, Alpe Cucco, 20.VII.2009 (CMB); Messina province, Portella Obolo, 16.VI-7.VII.2006, P. Rapuzzi \& G. Sama leg., 4 males and 3 females (CPR); Messina province, Mt. Soro, 16.VI-7.VII.2006, P. Rapuzzi \& G. Sama lgt., 4 males +1 female (CPR); Palermo province, Gibilmanna, 15.VI-6.VII.2006, P. Rapuzzi \& G. Sama leg., 1 female (CPR); Madonie Mountains, 1430 m., Piano Battaglia, 15.VI6.VII.2006, P. Rapuzzi \& G. Sama leg. (CPR); Madonie Mountains, Vallone Pomeri, 1300-1500 m., 14.VI-5/6.VII.2006, P. Rapuzzi \& G. Sama leg., 11 males +7 females (CPR); Madonie Mountains, Piano Zucchi, 1300 m., 13.VI-8.VII.2006, P. Rapuzzi \& G. Sama leg., 4 males (CPR); idem, 6.VII.1991, P. Rapuzzi leg., 1 female (CPR); Madonie Mountains, Castelbuono, Rifugio Crispi, m.1300,4.VI-7.VII.2019, M. Malmusi lgt. (CSN); 1 female; Madonie Mountains, Piano Zucchi, 12001300 m., 2.VI.2019, ex larva Fagus sp., S. Nappini leg., 1 male and 1 female (CSN). Madonie Mountains, Gibilmanna, loc. Piano delle Fate, 795 m., 16.VI-6.VII.2019, 1 male, M. Trentini leg. (CMC); Madonie Mountains, Piano Battaglia, 1639 m., 3 males, $37^{\circ} 52^{\prime} 46^{\prime \prime} \mathrm{N} \quad 14^{\circ} 30^{\prime} 18^{\prime \prime} \mathrm{E}, \quad 21 . \mathrm{VI}-$ 19.VII.2020 (CPR); Nebrodi (Messina province), $\mathrm{N}$ of Capizzi, 1419 m., 1 male, 3753'33' $\mathrm{N}$ 1401'25' E, 20.VI-18.VII.2020 (CPR); Malabotta Forest (Messina province), 1188 m., 37 58'19'”N 1503'19''E, 18.VI-16.VII.2020 1 male (CPR); Malabotta Forest (Messina province), $1224 \mathrm{~m}$., 3758'22”'N 1503'06' 'E, 18.VI-16.VII.2020, 1 male (CPR); Madonie Mountains, Baita dei Faggi 1336 m., $37^{\circ} 52^{\prime} 39^{\prime \prime} \mathrm{N} \quad 4^{\circ} 00^{\prime} 32^{\prime \prime} \mathrm{E}, \quad 21 . \mathrm{VI}-$ 
19.VII.2020, 1 female (CPR); Malabotta Forest (Messina province) $37^{\circ} 58^{\prime} 29^{\prime \prime} \mathrm{N} 15^{\circ} 03^{\prime} 04^{\prime}$ 'E, 1218 m., 18.VI-16.VII.'20, 1 male (CPR); Nebrodi (Messina province), Portella Obolo $1502 \mathrm{~m}$., 3754'00”N 14 30'07'”, 20.VI-18.VII.2020, 2 males (CPR).

Neopiciella kabyliana (Figs. 4, 5). Tunisia, Jendoouba, Aïn Draham, 1000 m., ex larva Quercus suber, sfarf. 3.VI.1991 G. Sama legit, 2 females (CGS); Algeria, Tizi Ouzou, Parc Nat. d'Akfadou, 1000-1400 m., ex larva Quercus mirbecki, 9.V.1987, G. Sama legit, 2 females (CGS).

Description OF HOLOTYPE. Length $1.01 \mathrm{~mm}$. Body elongated, covered by fine and erect yellow setae denser on the pronotum and elytra sides. Head, pronotum, antennae, legs, and underside black; elytrae yellow with sides and apex blackish. Head elongated, feebly inclined forwards, irregularly punctured with a thin and deep median furrow. Antennal tubercles rounded and well separated.

Eyes globose, finely facets, emarginated at upper side, widely separated from the basis of mandibles. Antennae long and robust with thickened end segments, finely pubescent, inserted between the eyes and surpassing the elytral apex beyond almost all of the last segment. Scape densely punctured, fourth segment one third shorter than third, last segment slightly longer than the penultimate (ratio 1.16). Mandibles rather narrow and short, acute apically. Maxillary palpi with apical articles elongated, slightly wider in the basal third, truncated apically.

Pronotum slightly longer than wide, convex at the middle, narrowed forward and wider at the base with protruding posterior angles, sides with a rounded projection just ahead of the middle, with a long smooth median line from the base to the middle. Punctures wide, deep and well-spaced on the middle, smaller at front margin, juxtaposed and confused at the base.

Elytra less than three times longer than broad together, basis distinctly wider than pronotum, sides subparallel, narrower towards the apex, depressed along the entire side of whole length of the suture, sutures finely reboarded, surface covered by strong,

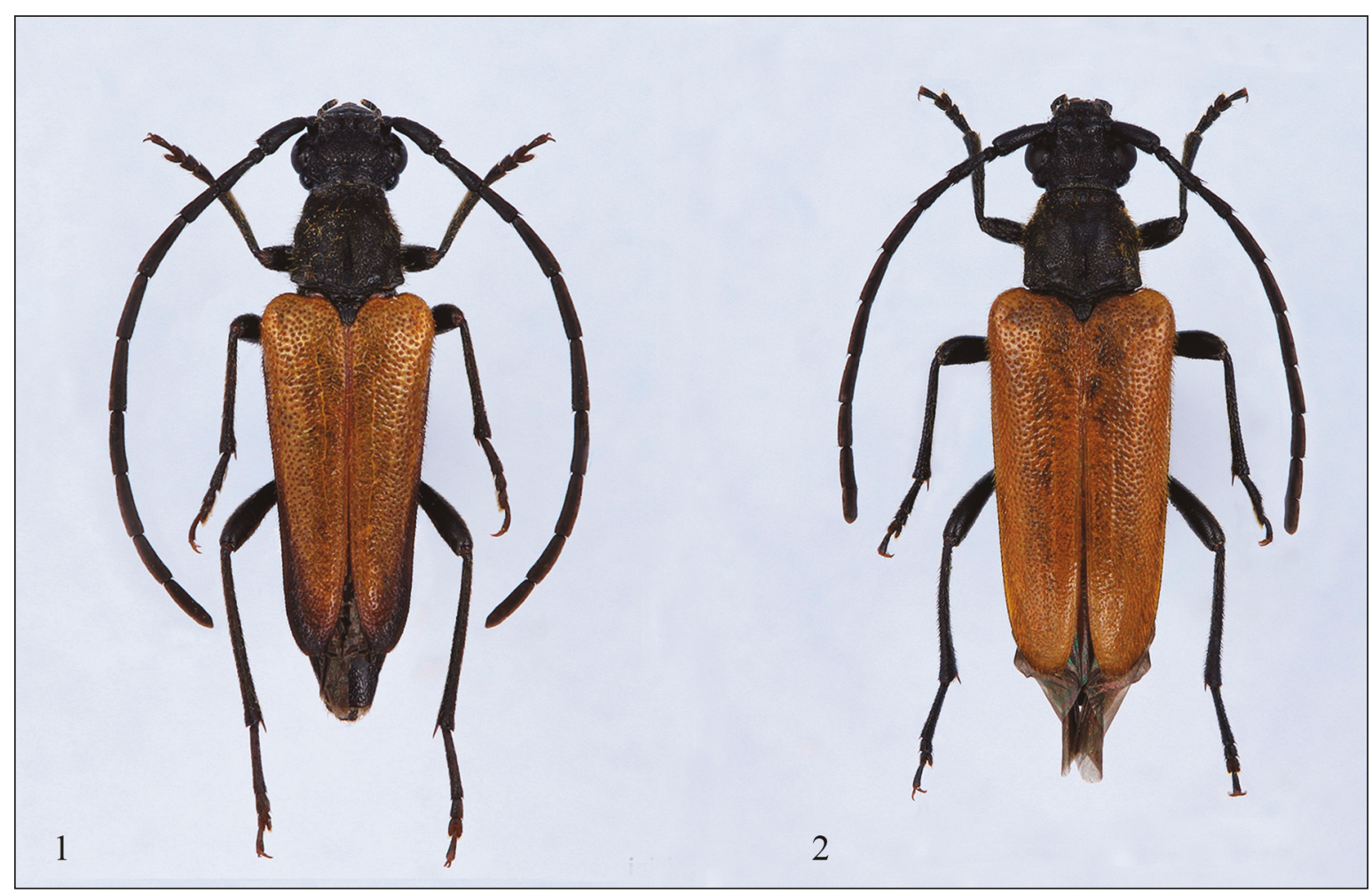

Figure 1. Neopiciella stefaniae n. sp., holotype male, Italy, Sicily, Trapani, Castellammare del Golfo, Monte Inici, 12.VI.2009. Figure 2. Neopiciella stefaniae n. sp., paratype female, same data of holotype. 
large, irregular and dense punctures. Epipleurae well visible behind the humeri until the apex. Legs long with surface very finely punctured. Femora slightly curves, tibiae linear, Tarsi long, 2nd article shorter than the 3rd; onychium slightly toothed at the base.

Underside: prosternum with large and very superficial points, prosternum apophysis with enlarged apex and subrettilinear border; metasternum with thin median furrow, densely and finely punctured and with anterior apophysis broad and hollow in the center; sternites hollowed in the center with very small and very sparse points.

VARIABILITY. The male paratypes have no substantial morphological differences with the holotype described. The length is $0.95-1.05 \mathrm{~mm}$, the blackish color of the elytra is sometimes more extensive. The females (Fig. 2) are larger (length 1.05-1.2 mm), with a more robust looking body, shorter antennae, prostrate apophysis hollowed in the center.

ETYMology. The species is named after Stefania Zaccolo from Cagliari (Sardinia, Italy), the first author's partner.
Distribution And Biology. Neopiciella stefaniae $\mathrm{n}$. sp. is known, at the moment, only of the typical localities, in the westernmost part of Sicily. This new species seems to replace the similar $N$. sicula more widely diffused in the central-eastern part of the island, along the northern mountain ridge from the Peloritani to the Sicani Mountains and around Palermo (see Figs, 5, 6).

Neopiciella kabyliana is endemic from North Africa (Fig. 5): Algeria (Forêt de la Yakouren, La Calle, Djebel Edough, Guelma) and Tunisia (El Feidja) (see Villiers, 1946).

The biology of $N$. stefaniae $\mathrm{n}$. sp. is unknown. Very likely it is similar to the other species of the genus. The larvas of Neopiciella feed between alive and dead wood of the stump of branches of the hosts. In some way it is very similar to the biology of $P e$ dostrangalia Sokolv, 1896. All the known specimens were collected using sugar traps hanged on trees of Quercus ilex L. and Quercus suber L. It is very likely that these plants are the host of the new species.

Neopiciella sicula develops in the larval stage of dead parts plants living as Fagus sylvatica and Quer-

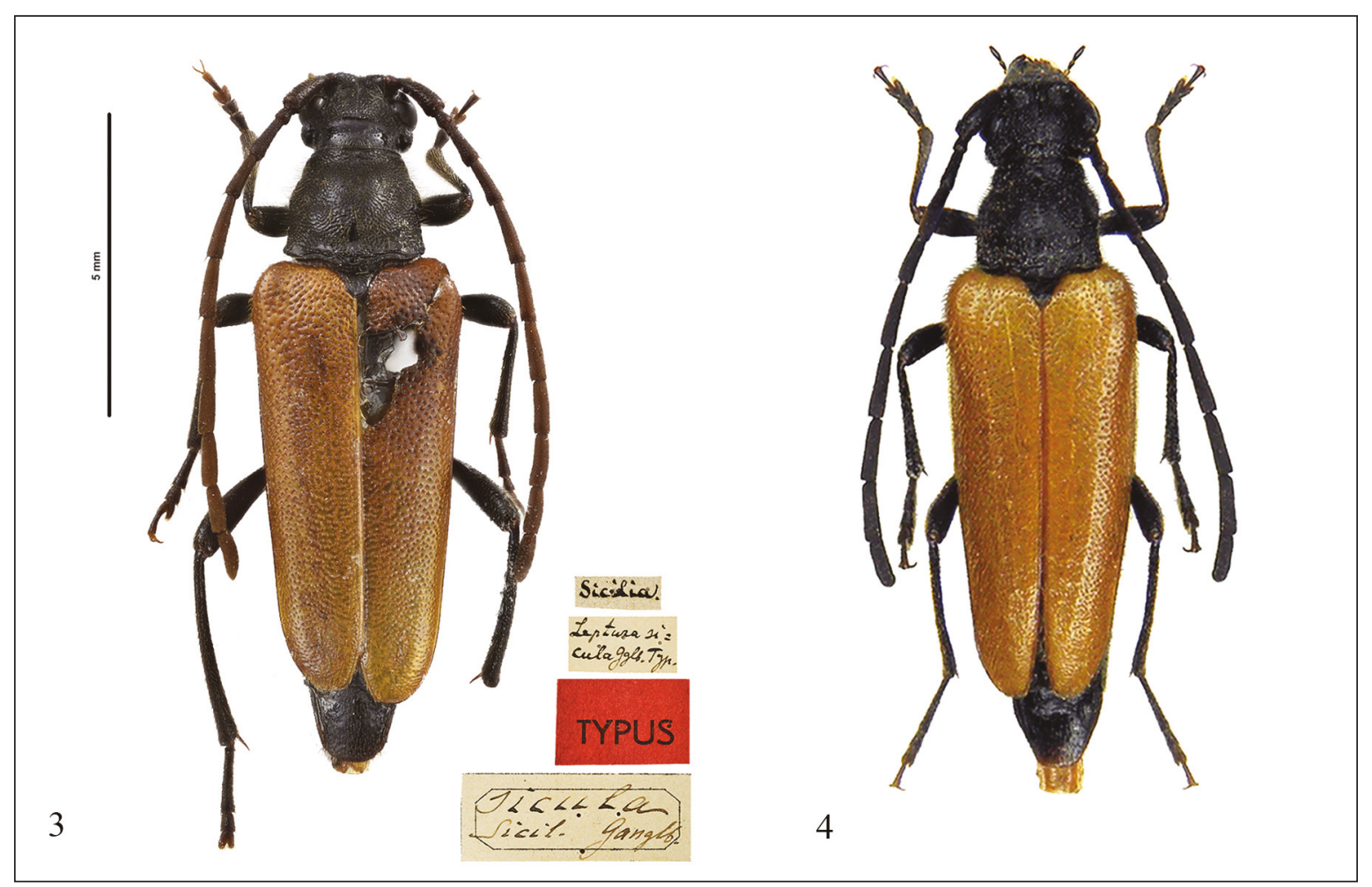

Figure 3. Neopicella sicula, holotype female. Figure 4. Neopiciella kabyliana female, Algeria, Tizi Ouzou, Parc Nat. d'Akfadou, 1000-1400 m. 


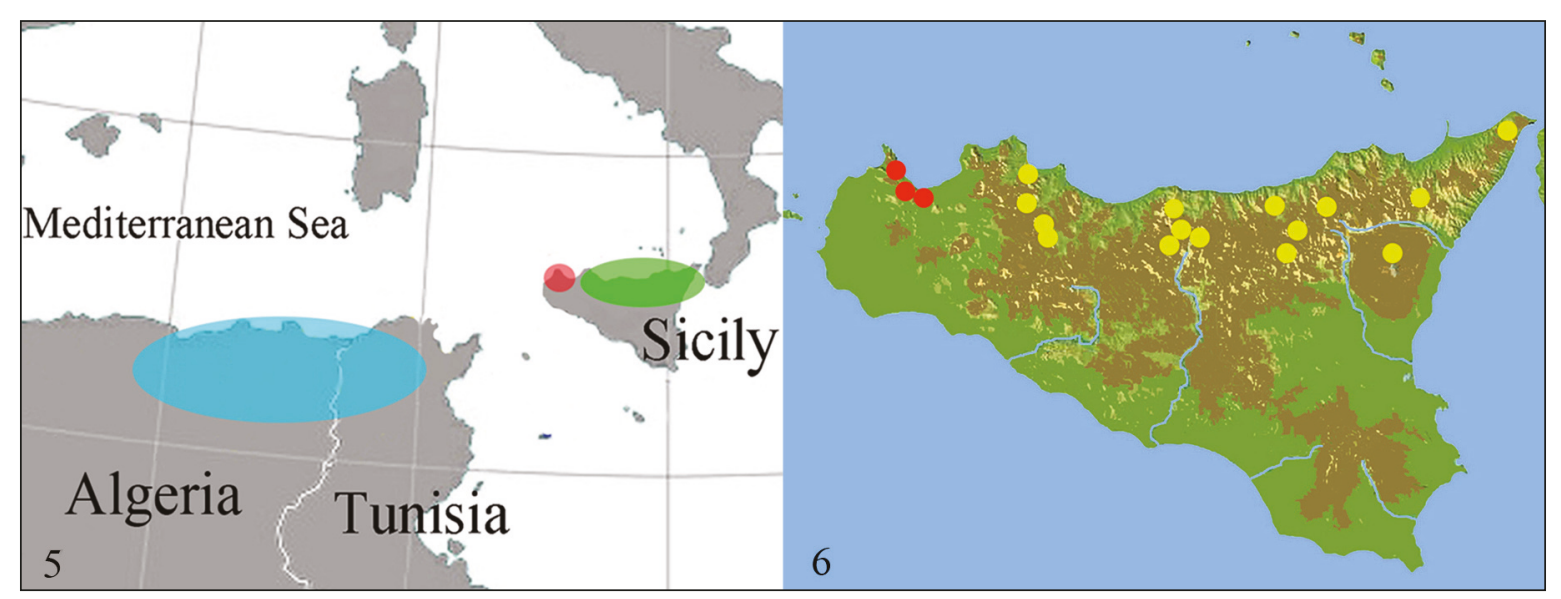

Figure 5. Maps of the genus Neopiciella: green $=N$. sicula, red $=N$. stefaniae n. sp., blue $=N$. kabyliana . Figure 6. Maps of N. sicula and N. stefaniae n. sp. in Sicily.

cus (Sama \& Schurmann, 1982) Acer campestre, A. pseudoplanatus (Sama, 1988). Neopiciella kabyliana was found on Quercus suber L. (Villiers, 1946).

The rarity of these Neopiciella species, and most likely also of $N$. stefaniae n. sp., is due to strictly arboreal habits of this beetles, rarely found on flowers or bushes.

REMARKS. Neopiciella stefaniae n. sp. is immediately distinguishable by the punctuation of the pronotum and, above all, of the elytra stronger, larger and denser punctures. In N. sicula and $N$. kabyliana this punctuation is smaller and more distant. The females of the new species show a shorter and stouter elytra, longer and parallel in the other known species.

Neopiciella stefaniae n. sp. differs from $N$. sicula for the last segment slightly longer than the penultimate (in males the ratio is 1.16 in $N$. stefaniae n. sp., 1.25 in N. sicula), the punctures of the underside smaller and more spaced, especially on the sternites, the prosternum apophysis of the males with subrettilinear apex (concave in $N$. sicula).

There are no significant differences between the aedeagus and tegmen of the new species compared with $N$. sicula. The apex is little more acuminate and the tegmen is little shorter in the new species. The 8th tergite of $N$. stefaniae n. sp. is evidently emarginate at the apex and about truncate in $N$. sicula.
It differs from $N$. kabyliana by the median shining line on the disk of the pronotum that is only on the basal half (this character is similar in N. sicula). The new species shows the sides of pronotum sinuate, similar with $N$. kabyliana, in N. sicula pronotum is smaller with the lateral sides more or less straight, with very small prominences on the middle. The punctuation is really deeper than both the other species of the genus. Tegmen of the new species is a little stouter than in N. sicula. Aedeagus is similar in both the species. We haven't seen any male of $N$. kabyliana.

\section{ACKNOWLEDGEMENTS}

We are greatfull to dr. Harald Schillhammer of the National History Museum of Wien (Austria) that provided us with the picture of the type specimen of Leptura sicula Ganglbauer, 1885 preserved in his Museum.

\section{REFERENCES}

Bellavista M., Sparacio I., Giardina G. \& La Mantia T., 2008. Biodiversità dei Coleotteri Cerambicidi del Bosco della Ficuzza (Monti Sicani, Sicily) in relazione ai caratteri della vegetazione. In: Biodiversità e Biogeografia della Sicilia. XXXVII Congresso della Società Italiana di Biogeografia (Catania, Oct. 
7-10, 2008) (poster available at Edizioni Danaus, visited on $01 / 27 / 2017)$.

Baviera C. \& Sparacio I., 2002. Coleotteri nuovi o poco conosciuti di Sicilia II. Il Naturalista siciliano, 26: 77-92.

Baviera C., Bellavista M., Altadonna G., Fabrizio Turrisi G., Bella S., Muscarella C. \& Sparacio I., 2017. The Cerambycidae (Coleoptera: Chrysomeloidea) of Sicily: recent records and updated checklist. Atti della Accademia Peloritana dei Pericolanti Classe di Scienze Fisiche, Matematiche e Naturali, 95: 1-79.

Carpaneto G.M., Baviera C., Biscaccianti A.B., Brandmayr P., Mazzei A., Mason F., Battistoni A., Teofili C., Rondinini C., Fattorini S. \& Audisio P., 2015. A Red List of Italian Saproxylic Beetles: taxonomic overview, ecological features and conservation issues (Coleoptera). Fragmenta entomologica, 47: 53-126. DOI: $10.4081 /$ fe.2015.138.

La Mantia T., Bellavista M., Giardina G. \& Sparacio I., 2010. Longhorn beetles of the Ficuzza woods (W Sicily, Italy) and their relationship with plant diversity (Coleoptera, Cerambycidae). Biodiversity Journal, 1: 15-44.

Pic M., 1896. Xylophilides et Anthicides recueillis en Algérie Mai-Juin 1896. Revue Scientifique du Bourbonnais et du Centre de la France, 9: 103.

Ragusa E., 1924. I Cerambycidae della Sicilia. Bollettino della Reale Accademia delle Scienze, Lettere e Belle Arti di Palermo, 14: 1-33.

Rapuzzi P., 2010. Neopiciella sicula (Ganglbauer, 1885). http://www.entomologiitaliani.net/public/forum/php BB3/viewtopic.php?f $=145 \& \mathrm{t}=4464$

Rapuzzi P. \& Sama G., 2006. Cerambycidae nuovi o interessanti per la fauna di Sicilia (Insecta Coleoptera Cerambycidae). Quaderno di Studi e Notizie di Storia Naturale della Romagna 23: 157-172.

Rapuzzi P., Biscaccianti A.B. \& Baviera C., 2014. Co- leoptera Cerambycidae. In: Lista Rossa IUCN dei Coleotteri Saproxilici Italiani. Ed. by P. Audisio, C. Baviera, G. M. Carpaneto, A. B. Biscaccianti, A. Battistoni, C. Teofili, and C. Rondinini. Roma: Comitato italiano IUCN e Ministero dell'Ambiente e della Tutela del Territorio e del Mare.

Sabella G. \& Sparacio I., 2004. Il ruolo dei parchi siciliani nella conservazione di taxa di insetti di particolare interesse naturalistico (Insecta Coleoptera et Lepidoptera Rhopalocera). Il Naturalista siciliano, 28: 477-508. http://www.sssn.it/PDF/PDF\%20Nat. $\% 20$ Sic\%201\%202004/Sabella\&Sparacio_477-508. pdf.

Sama G., 1988. Coleoptera Cerambycidae. Catalogo Topografico e Sinonimico. XXVI. In: Checklist and distribution of the Italian fauna. Ed. by S. Ruffo and F. Stoch. Vol. 36. Fauna d'Italia. Bologna: Calderini, pp. 1-26.

Sama G., 2005. Insecta Coleoptera Cerambycidae. In: Ruffo \& Stoch F. (Eds.), Checklist e distribuzione della fauna italiana. Memorie del Museo Civico di Storia Naturale di Verona, 2. Serie, Sezione Scienze della Vita 16, pp. 219-222.

Sama G. \& Schurmann P., 1980. Coleotteri Cerambicidi di Sicilia. Animalia, 7: 189-230.

Sparacio I., 1999. Coleotteri di Sicilia (vol. III). Palermo: L'Epos editore, pp. 1-192.

Villiers A., 1946. Coléoptères de l'Afrique du Nord. Faune de l'Empire Francais, V. Office de la Recherce Scientificque Coloniale, Ed. du Museum, Paris, 154 pp.

Vitale F., 1936. I longicorni siciliani. Atti della Reale Accademia Peloritana. Classe di Scienze Fisiche, Matematiche e Biologiche, 14: 75-101. 